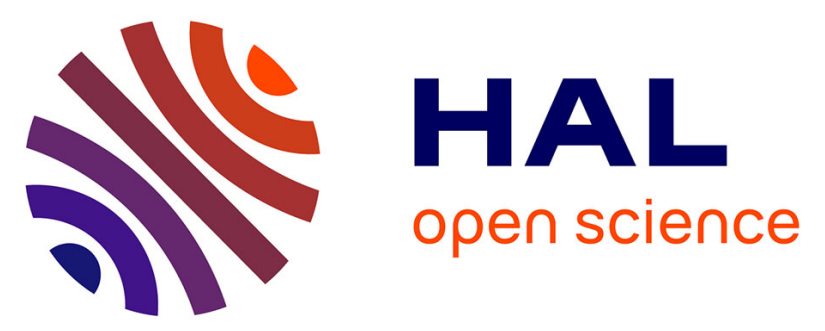

\title{
Detailed record of the mid-Oxfordian (Late Jurassic) positive carbon-isotope excursion in two hemipelagic sections (France and Switzerland): A plate tectonic trigger?
}

Beat Louis-Schmid, Pauline Rais, Stefano M. Bernasconi, Pierre Pellenard, Pierre-Yves Collin, Helmut Weissert

\section{To cite this version:}

Beat Louis-Schmid, Pauline Rais, Stefano M. Bernasconi, Pierre Pellenard, Pierre-Yves Collin, et al.. Detailed record of the mid-Oxfordian (Late Jurassic) positive carbon-isotope excursion in two hemipelagic sections (France and Switzerland): A plate tectonic trigger?. Palaeogeography, Palaeoclimatology, Palaeoecology, 2007, 248 (3-4), pp.459-472. 10.1016/j.palaeo.2007.01.001 . hal-00203716

\section{HAL Id: hal-00203716 https://hal.science/hal-00203716}

Submitted on 28 Apr 2020

HAL is a multi-disciplinary open access archive for the deposit and dissemination of scientific research documents, whether they are published or not. The documents may come from teaching and research institutions in France or abroad, or from public or private research centers.
L'archive ouverte pluridisciplinaire HAL, est destinée au dépôt et à la diffusion de documents scientifiques de niveau recherche, publiés ou non, émanant des établissements d'enseignement et de recherche français ou étrangers, des laboratoires publics ou privés. 


\title{
Detailed record of the mid-Oxfordian (Late Jurassic) positive carbon-isotope excursion in two hemipelagic sections (France and Switzerland): A plate tectonic trigger?
}

\author{
Beat Louis-Schmid $^{\text {a,* }}$, Pauline Rais ${ }^{\text {a }}$, Stefano M. Bernasconi ${ }^{\text {a }}$, Pierre Pellenard ${ }^{\text {b }}$, \\ Pierre-Yves Collin ${ }^{\mathrm{c}}$, Helmut Weissert ${ }^{\mathrm{a}}$ \\ ${ }^{a}$ Geologisches Institut, ETH Zürich, 8092 Zürich, Switzerland \\ ${ }^{\mathrm{b}}$ UMR CNRS 5561 Biogeosciences, Université de Bourgogne, Centre des Sciences de la Terre, 6 bd Gabriel, 21000 Dijon, France \\ ' Université P. \& M. Curie, UMR CNRS 5143 "Paléobiodiversité \& Paléoenvironnements", Tours 56-66/E5, \\ Case 117, 4, place Jussieu, 75252 Paris cedex 05, France
}

\begin{abstract}
The Oxfordian (Late Jurassic) was a time of widespread change in Jurassic marine (carbonate) sedimentation patterns. A marked positive excursion in $\delta^{13} \mathrm{C}$ is dated as Middle Oxfordian in age. In this study we investigate if changes in carbonate sedimentation coincided with altered carbon cycling and climate. We use $\mathrm{C}$-isotope records as a proxy for the evolution of the carbon cycle and compare $\delta^{13} \mathrm{C}$-trends with the evolution of sedimentation in a segment of the opening Tethys seaway. One of the studied sections is located in the Subalpine basin of France (Trescléoux and Oze), the other in the Swiss Jura mountains (Liesberg). Carbon-isotope stratigraphy of carbonate carbon locates the peak values of the Middle Oxfordian positive excursion to the antecedens and parandieri subzones of the plicatilis and transversarium ammonite zones, respectively. Causes of the excursion remain enigmatic. The excursion seems not to coincide with a global oceanic anoxic event, but regionally enhanced organic carbon accumulation during the Early and early Middle Oxfordian may be the cause of the increase in $\delta^{13} \mathrm{C}$. The excursion occurs during a time of progressive climate warming, and its peak values coincide with the first calcareous sediments recurring after a period of reduced carbonate accumulation in the Early and early Middle Oxfordian. The excursion is also time-equivalent to a major reorganisation of global ocean currents: the opening Atlantic and Tethys oceans combined with rising sea level led to the formation of an efficient circumglobal seaway. We conclude that this favoured the widespread recurrence of carbonate producers by providing new habitats. As a result, $\mathrm{C}_{\text {carb }}$ burial increased, leading to a lower $\mathrm{C}_{\text {org }} / \mathrm{C}_{\text {carb }}$ burial rate and therefore to stabilisation and decrease in $\delta^{13} \mathrm{C}$ in the Middle Oxfordian. Thus, the mid-Oxfordian positive excursion in carbonate $\mathrm{C}$-isotopes may reflect changes in the carbon cycle that were triggered by a copious reorganisation of the ocean current system caused by major plate tectonic movements.
\end{abstract}

Keywords: Oxfordian; Carbon stable isotopes; Carbon cycle; Tethys; Climate; Palaeo-oceanography

* Corresponding author. Fax: +41446321075.

E-mail address: beat.louis@alumni.ethz.ch (B. Louis-Schmid).

\section{Introduction}

The reconstruction of past changes in climate and oceanography is crucial to our understanding of how climate, biosphere and geosphere are linked. The 
Oxfordian (Late Jurassic) was a time of global change in the marine sedimentation pattern (Dromart et al., 2003a). In the European Tethys realm, the Late Callovian and Early Oxfordian are characterised by reduced carbonate deposition: sediments are either absent, condensed and iron-rich (Collin et al., 2005), or appear as thick, organic carbon-rich shaly (e.g. Terres Noires (de Graciansky et al., 1999)) or siliceous deposits (e.g. Radiolarites (Bartolini et al., 1996)). Then, in Middle to Late Oxfordian, a change to widespread carbonate sedimentation took place (Dromart et al., 2003a). This change in sedimentation seems to correlate with a positive anomaly in both marine and terrestrial carbonisotope records of the Middle Oxfordian documented by many studies (Bartolini et al., 1996; Jenkyns, 1996; Lavastre, 2002; Price and Gröcke, 2002; Wierzbowski, 2002; Maheshwari et al., 2003; Katz et al., 2005; Pearce et al., 2005). However, these records are either of low resolution or poorly dated.

Climate was also subject to major changes during the Oxfordian: a comparatively cold and humid period in the Late Callovian-Early Oxfordian was followed by a considerably warmer and regionally more arid climate in the Middle-Late Oxfordian, a fact recorded in both hemispheres and at different palaeolatitudes (Vakhrameev, 1991; Bausch et al., 1998; Riboulleau et al., 1998; Riding and Hubbard, 1999; van Aarssen et al., 2000; Abbink et al., 2001; Malchus and Steuber, 2002; Dromart et al., 2003b; Gröcke et al., 2003; Lécuyer et al., 2003).

Combined with the ongoing opening of the Atlantic and the Tethys (Gradstein et al., 1991; Ziegler et al., 2001; Stampfli and Borel, 2002), the Late Jurassic longterm sea-level rise (Haq et al., 1988; Hallam, 2001) led to a reorganisation of ocean currents in the TethysAtlantic system during the Oxfordian (Ager and Walley, 1977; Vörös, 1993; Stille et al., 1996; Pellenard et al., 1999; Bombardiere and Gorin, 2000; Bill et al., 2001; Leinfelder et al., 2002; Rais et al., 2005).

The Oxfordian is characterised by the lowest values in seawater- ${ }^{87} \mathrm{Sr} /{ }^{86} \mathrm{Sr}$ in the Phanerozoic (Jenkyns et al., 2002). This could be related to decreased input of radiogenic $\mathrm{Sr}$ from continental erosion or to increased input of mantle strontium with a low ${ }^{87} \mathrm{Sr} /{ }^{86} \mathrm{Sr}$ ratio. Increased mantle $\mathrm{Sr}$ input to the ocean is supported by a recent study (Cogné and Humler, 2004) which postulates exceptionally high overall seafloor spreading rates for the time between 160 and $154 \mathrm{My}$, corresponding roughly to the Oxfordian (Gradstein et al., 2004), and by the known spreading of many oceans (Gradstein et al., 1991; Ziegler et al., 2001; Stampfli and Borel, 2002). In addition, the continental large igneous prov- ince of Patagonia was partly formed in the Oxfordian (Féraud et al., 1999).

Carbon-isotope records of marine carbonate are a useful proxy of the carbon cycle (Weissert, 1989; Weissert and Mohr, 1996; Padden et al., 2002). In this study, we present detailed C-isotope records of the Early to Middle Oxfordian from France and Switzerland. We investigate the relationship between C-isotope evolution, facies changes, carbon cycling and sea level, and discuss mechanisms that could account for the mid-Oxfordian positive $\mathrm{C}$-isotope excursion. The study focuses on the northern margin of the Alpine Tethys (Fig. 1). As this region was close to the confluence of the opening Atlantic and the Tethys ocean, it likely responded sensitively to changes in global ocean circulation patterns. The area of study also includes hemipelagic to pelagic environments, which are influenced only to a minor extent by land areas, but are still shallow enough to record changes in sea level. These offshore environments are characterised by high sedimentation rates and allow good dating. We measured two (composite) sections in southeastern France (Trescléoux/Oze) and the Swiss Jura (Liesberg), which provide a good age control by ammonite stratigraphy (Figs. 1, 2). The French section represents the deepest parts of the epeiric southeastern France Subalpine basin, whereas the Swiss section comes from a shallower platform setting. We established carbon-isotope records for both sites, with an estimated average sample resolution of approximately 10 to $20 \mathrm{ky}$, based on the geologic timescale of Gradstein et al. (2004). These records combined allow location of the positive excursion in the $\delta^{13} \mathrm{C}$-record to the Middle Oxfordian Perisphinctes plicatilis and Gregoryceras transversarium zones and relating changes in carbon cycling with major changes in marine sedimentation pattern.

\section{Analytical procedures}

For carbon- and oxygen-isotope and carbonate content analyses, marlstone and limestone samples (no nodules) from the two sections were first cut or broken, and then drilled on the fresh surface with a diamondcoated micro-drill bit. To prevent contamination, we carefully avoided alteration crusts, roots, secondary cement and mineralizations while drilling. Bulk-carbonate carbon- and oxygen-isotopes were measured on a VG Prism mass spectrometer equipped with an automated carbonate preparation module. Samples were reacted in $100 \%$ phosphoric acid at $90{ }^{\circ} \mathrm{C}$ to obtain $\mathrm{CO}_{2}$. Precision of measurement, based on 


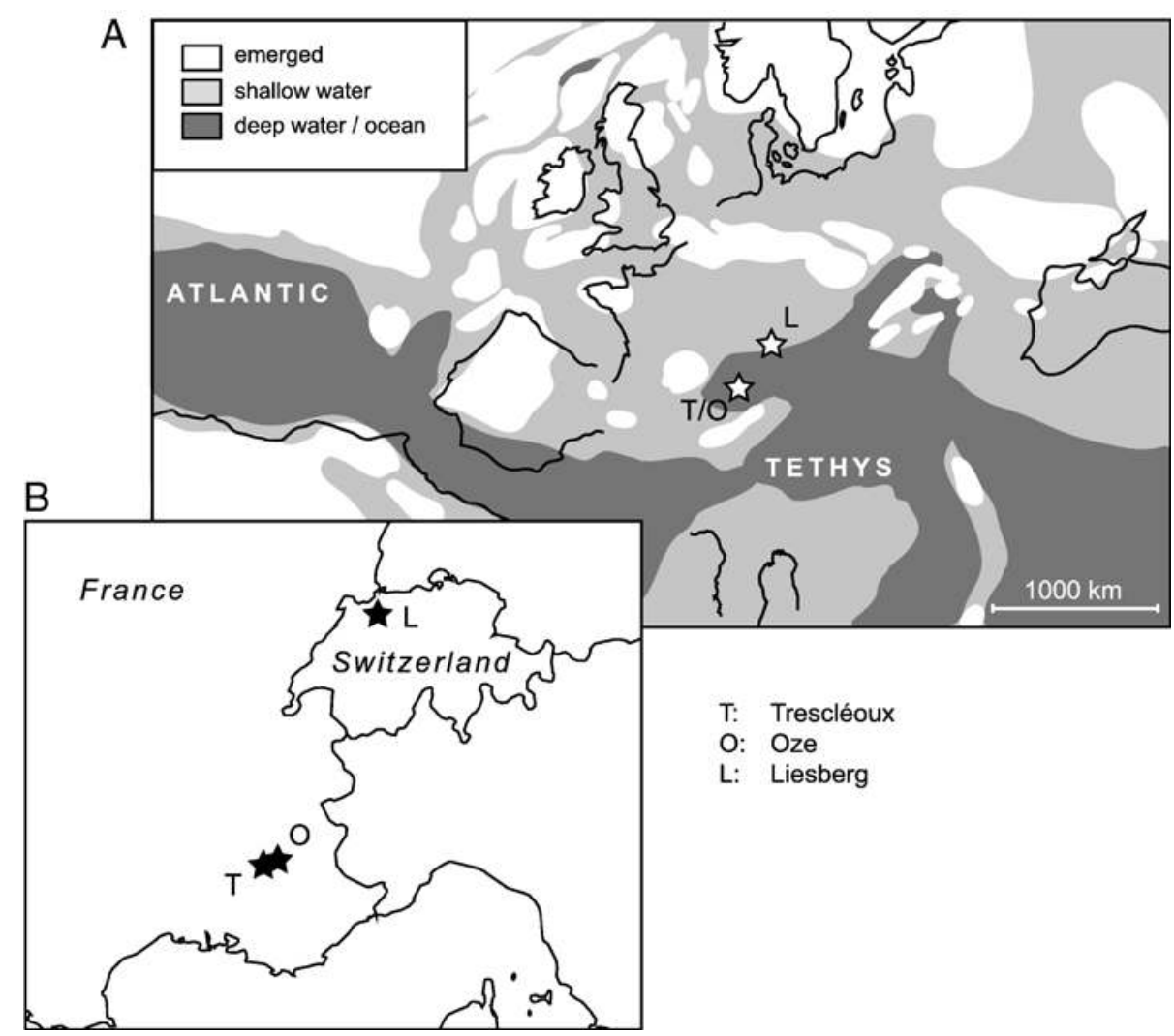

Fig. 1. Location map (A) and palaeogeography (B) of the studied sections. $\mathrm{L}=$ Liesberg, $\mathrm{T}=$ Trescléoux, $\mathrm{O}=\mathrm{Oze}$, black lines represent modern coast lines and state borders. Palaeomap modified after Ziegler (1988).

repeated measurements of a laboratory-internal standard (Carrara marble) calibrated against Vienna PDB (VPDB), is better than $\pm 0.1 \%$ o for carbon and oxygen. All isotope values are reported in standard delta notation relative to VPDB. Inorganic carbon contents of the samples were determined with a UIC CM $5012 \mathrm{CO}_{2}$ Coulometer coupled to the acidification module $\mathrm{CM}$ 5130. Weighed samples were reacted with $2 \mathrm{~N}$ perchloric acid $\left(\mathrm{HClO}_{4}\right)$, and the amount of evolving $\mathrm{CO}_{2}$ was measured by titration. Measurement precision based on standards, expressed in weight- $\%$ carbonates, is better than $\pm 1.4 \%$.

\section{Study sites}

\subsection{Trescléoux and Oze (southeastern France, Fig. 1)}

The Trescléoux section was previously studied in terms of sedimentology, biostratigraphy and sequence stratigraphy (Gaillard et al., 1996; Pellenard, 2003; Gaillard et al., 2004). We measured two separate parts (Fig. 2), outcropping at a distance of about $500 \mathrm{~m}$ from each other. The lower part is exposed on a hill slope adjacent to the village of Trescléoux. It belongs to the so called Terres Noires and consists of grey to black marlstones, which contain layers of carbonate nodules parallel to the bedding. These nodules are circular to oval in cross section, and about 3 to $10 \mathrm{~cm}$ in diameter. They become more abundant in the upper part of the section. For isotope analyses, we sampled only marlstones, with a resolution of about one sample each metre.

The upper part of the section belongs to the so called Argovien. This facies consists of an alternation of marlstones and limestones. The base of the Argovien is very distinct in the field, thus providing a good correlation line. The Argovien replaces the Terres Noires synchronously in the whole Subalpine basin, marking the top part of the Perisphinctes antecedens ammonite subzone (D. Fortwengler, pers. comm.). Here we collected another 94 samples within $80 \mathrm{~m}$, from both marlstones and limestones.

Oze is situated around $50 \mathrm{~km}$ to the northeast of Trescléoux. We sampled the top of the Vertebriceras 


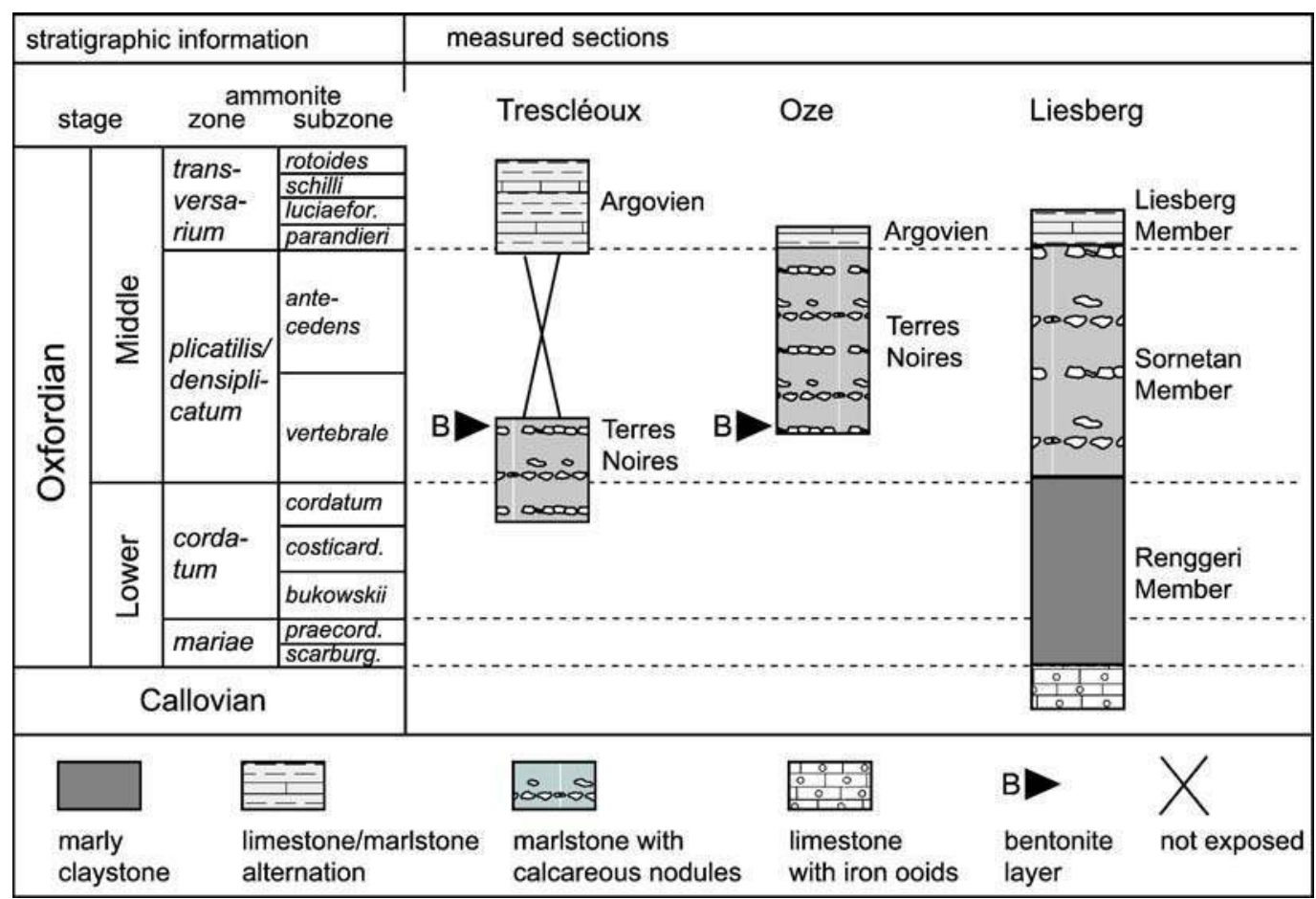

Fig. 2. Biostratigraphical correlation, lithology and formation names of the studied sections.

vertebrale and the whole antecedens ammonite subzone. This part is the direct stratigraphic precursor of the Argovien and could not be clearly identified and therefore not sampled at Trescléoux. The lithology is the same as in the lower part of Trescléoux, except that the nodules are bigger with diameters up to $20 \mathrm{~cm}$. For isotope analyses, we collected 112 marlstone samples within a height of $102 \mathrm{~m}$.

The French sections are dated by ammonite stratigraphy (Gaillard et al., 1996; Pellenard, 2003; Gaillard et al., 2004) with a resolution reaching the level of ammonite subzones and comprise the upper part of the Early Oxfordian Cardioceras cordatum to the top of the Middle Oxfordian transversarium ammonite zones (Fig. 2). Correlation between Trescléoux and Oze is specified by a remarkably thick bentonite layer (marked as B in Figs. 2 and 3) occurring in the vertebrale ammonite subzone (Pellenard, 2003; Pellenard et al., 2003).

\subsection{Liesberg (north-western Switzerland, Fig. 1)}

Previous studies on this section concentrated on sedimentology, palaeontology and biostratigraphy (Fischer, 1965; Gygi, 1990, 2000). The section consists of Callovian strata in the lower part, followed by the approximately $50 \mathrm{~m}$ thick Renggeri Member, a homogeneous, marly claystone without any visible bedding, the Sornetan Member (formerly named Terrain à chailles), an alternation of marlstones and layers with calcareous nodules, and the Liesberg Member, which is quite similar to the latter but with limestone layers and abundant ahermatypic corals (Fischer, 1965; Gygi, 2000). The section spans the Early Oxfordian Cardioceras mariae and cordatum ammonite zones, and the plicatilis and the earliest part of the transversarium zone of the Middle Oxfordian (Fig. 2). Biostratigraphical resolution reaches the ammonite subzone-level (Gygi, 1990, 2000). However, because of the scarcity of ammonites several boundaries between the different subzones had to be placed tentatively (Gygi, 1990). Their actual position may be up to tens of metres below or above the position indicated in the original literature.

\subsection{Use of biostratigraphical zone names}

Most Oxfordian sections in northern Switzerland were dated by Gygi (2000). Based on thousands of ammonites collected in-situ, he developed a regional ammonite stratigraphy which is different from the one proposed for southeastern France. To ease comparisons, 

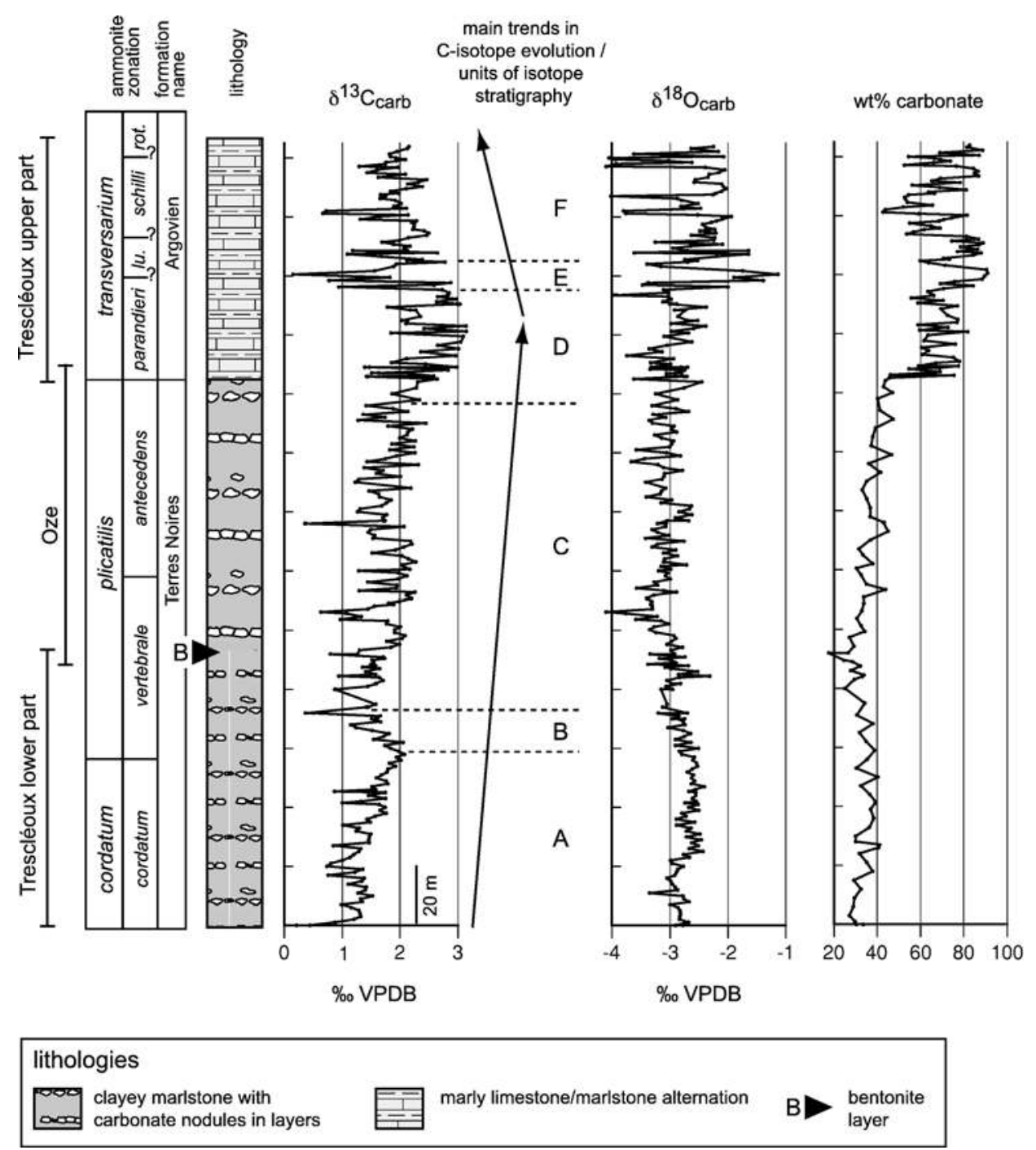

Fig. 3. Composite section from southeastern France (Trescléoux/Oze). Biostratigraphy, lithology and results for stable isotope measurements and carbonate content. See text for description of units in C-isotope evolution.

all names of ammonite zones in this article refer to the French zonation (except where noted).

\section{Results}

\subsection{Evolution of carbon-isotope ratios}

The combined C-isotope record of the French sections can be divided into six units, defining a pattern usable for correlation and stratigraphic purposes (Fig. 3). Unit A is marked by a rather continuous rise of the $\delta^{13} \mathrm{C}$-values from about $0 \%$ to $2 \%$. Unit B shows an interim drop to values around $1 \%$, while in unit $\mathrm{C}$, $\delta^{13} \mathrm{C}$-values oscillate around $1.5 \%$. Unit $\mathrm{D}$ is defined as the positive excursion in a strict sense, starting from values around $2 \%$ and reaching values of more than $3 \%$ at its maximum. These most positive values are almost immediately followed by a negative spike down to around $0.5 \%$ (giving an amplitude of $2.5 \%$ ), marking unit $\mathrm{E}$. Unit $\mathrm{F}$ shows a slight drop from values around $2.5 \%$ to values of $2 \%$. The most pronounced change in lithology, from the Terres Noires to the Argovien, takes place in the lower part of unit D.

Unit E, the negative spike, corresponds stratigraphically to the negative $\mathrm{C}$-isotope excursion documented by Padden et al. (2001). This event occurs in the transversarium zone and reaches in the Vergons section in southeastern France values down to about $-2 \%$, giving an amplitude of $4 \%$ for the negative excursion (Padden et al., 2001). In three sections from 
Switzerland, the event has a lower amplitude of about $1.5 \%$ and reaches absolute values around $+1 \%$ (Padden et al., 2001). Padden et al. (2001) propose that release of methane from gas hydrate led to this isotopic excursion. Investigations are in progress that should allow better identification of possible trigger mechanisms for this isotopic event.

The carbon-isotope curve for Liesberg shows the following pattern (Fig. 4): In the Renggeri Member values rise from $-1 \%$ to about $1.5 \%$, then stay around $1.5 \%$ in the Sornetan Member, which corresponds to unit $\mathrm{C}$ in the French section. A sharp increase of about $1 \%$ is observed within the transition between Sornetan Member and Liesberg Member (corresponding to the lower part of unit D of the French section). Values for the uppermost samples reach $2.5 \%$.

\subsection{Evolution of sedimentation and carbonate deposition}

The investigated Early and early Middle Oxfordian sediments (Terres Noires, Renggeri Member and Sornetan Member) are clayey marlstones and marl- stones with 20 to $40 \%$ carbonate (Figs. 3, 4). The carbonate consists of calcite dominated by micrite, but well-preserved coccoliths, parts of coccospheres and, in the Terres Noires, Protoglobigerines can be observed. Macrofossils are rare but dominated by ammonites and belemnites. Carbonate nodules, with up to $80 \% \mathrm{CaCO}_{3}$, are frequent in the Terres Noires and the Sornetan Member. They reach up to $30 \mathrm{~cm}$ in diameter. The Renggeri and Sornetan Members and the Terres Noires also have slightly elevated organic carbon contents (up to $1 \%$ TOC in the Renggeri Member, up to $0.8 \%$ in the Terres Noires). In the Terres Noires, non-decompacted average sedimentation rates reach about $100 \mathrm{~m} / \mathrm{My}$ (Jacquin et al., 1998).

In the Middle Oxfordian, at the base of the transversarium ammonite zone, a distinct facies change from the Terres Noires to the Argovien - occurred in the French section. In the Argovien, carbonate contents are generally higher than in the Terres Noires, but vary strongly between 50 and over $90 \%$. At Liesberg, the corresponding facies change is more subtle. It is indicated mainly by the first but copious occurrence of ahermatypic, platy corals. In the uppermost part of the

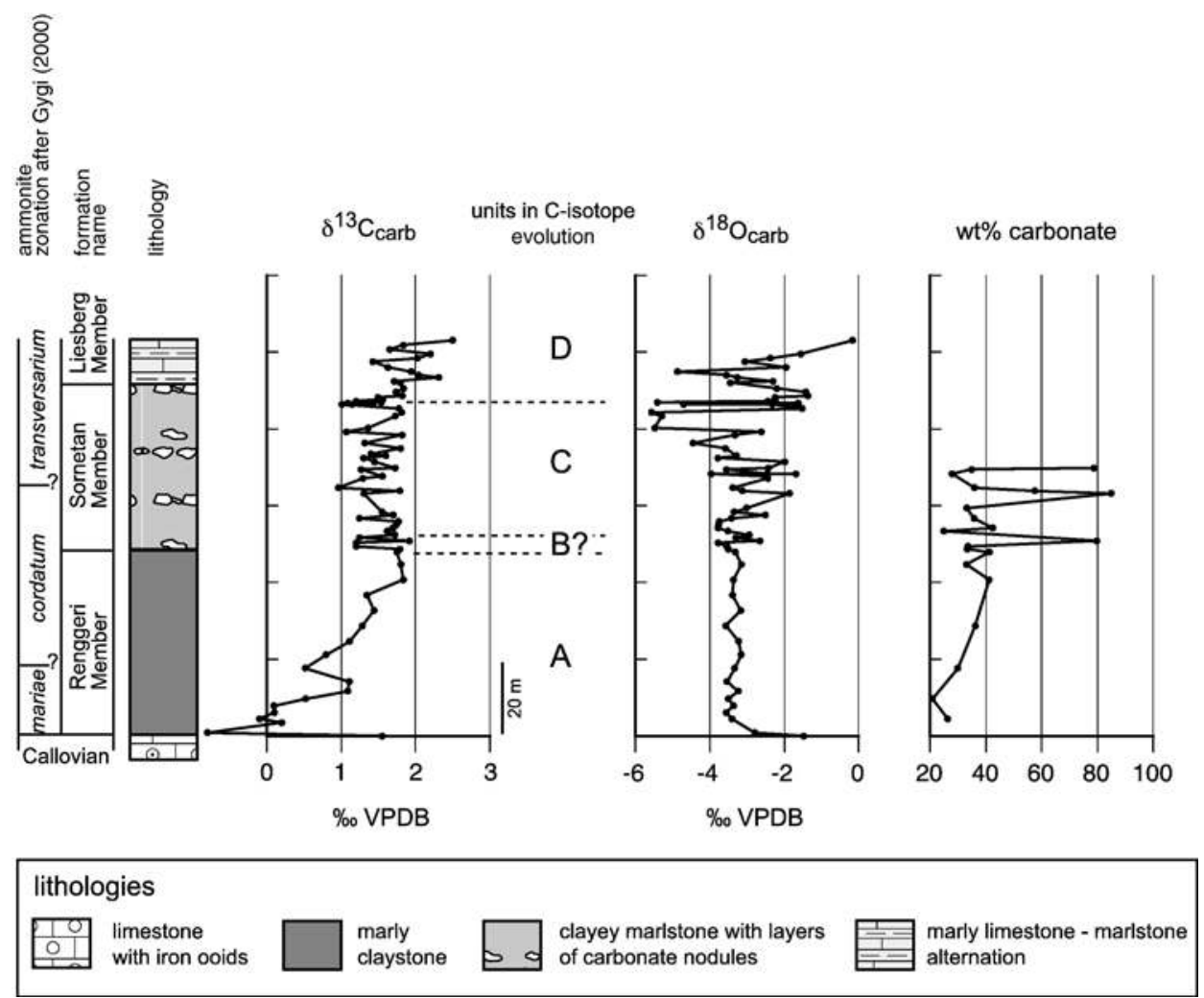

Fig. 4. Section from northern Switzerland (Liesberg). Biostratigraphy, lithology and results for stable isotope measurements and carbonate content See text for description of units in C-isotope evolution. 
studied section, limestones then become dominant. In comparison to the Renggeri and Sornetan Members, sedimentation rates decreased, indicating either the onset of more arid conditions on continents or changes in accommodation space (Gygi and Persoz, 1987). The Liesberg Member is followed by a succession of carbonate platform deposits, which were not investigated in this study.

\section{Discussion}

\subsection{Preservation and global significance of carbon-} isotope signals; use as reference section

Before discussing the possible global significance of the measured changes in the $\delta^{13} \mathrm{C}$-record, diagenetic or local lithological influences on the records have to be excluded. The measured carbonate consists of calcite composed of micrite, nannofossils (coccoliths) and microfossils (foraminifera). Coarse cements or dolomite have not been detected. Nannofossils in the clayey marlstones are very well-preserved, they show virtually no re-crystallisation nor overgrowth with cements (Fig. 5A). $\delta^{13} \mathrm{C}$ and $\delta^{18} \mathrm{O}$ do not show covariance (Fig. 5B). Still, the pronounced scatter in the $\delta^{18} \mathrm{O}$ records of the Argovien (Fig. 3) and the Liesberg and

\section{A}

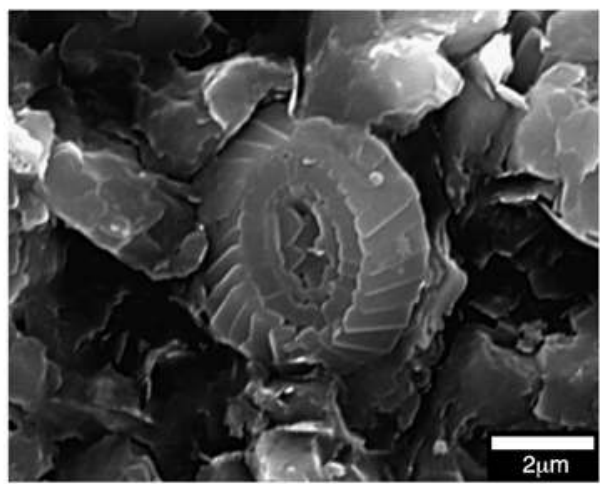

B
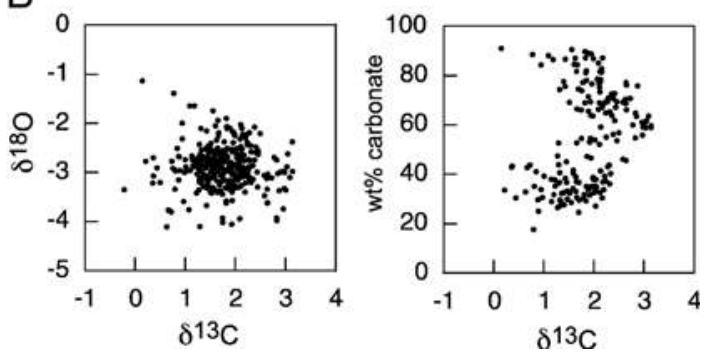

Fig. 5. SEM-image illustrating the good preservation of coccoliths. See scale bar for magnification (A). Cross-plot of $\delta^{13} \mathrm{C}$ vs. $\delta^{18} \mathrm{O}$ and $\delta^{13} \mathrm{C}$ vs. carbonate content of the French section (B).
Sornetan Members (Fig. 4) may indicate a diagenetic alteration of some of the O-isotope signals. We therefore do not use the O-isotope record as palaeoenvironmental indicator. It has been shown that carbon-isotope values are much less prone to diagenetic alteration than oxygen-isotope values (e.g. Weissert and Breheret, 1991; Vincent et al. 2004), and that commonly marine values are retained if the section went through burial diagenesis (Marshall, 1992). This was the case for the French sections as indicated by organic matter burial temperatures $\left(445{ }^{\circ} \mathrm{C}<T_{\max }<460{ }^{\circ} \mathrm{C}\right.$ ) (Pellenard, 2003). Furthermore, the similarity between our bulkrock records and several other records from different oceans and palaeoenvironments, measured on both marine - including belemnites - and terrestrial materials (Bartolini et al., 1996; Jenkyns, 1996; Lavastre, 2002; Price and Gröcke, 2002; Wierzbowski, 2002; Maheshwari et al., 2003; Katz et al., 2005; Pearce et al., 2005), indicates that diagenesis did not alter the $\mathrm{C}$-isotope record of the presented sections and that they carry a signal of global significance (Fig. 6).

The onset of the positive excursion in the $\delta^{13} \mathrm{C}$ record is located a few metres below the first limestone layer of the Argovien (Fig. 3). In addition, carbonate contents and $\delta^{13} \mathrm{C}$ do not show covariance (Fig. 5B). The decoupling of the $\delta^{13} \mathrm{C}$-record from carbonate contents indicates that the mid-Oxfordian positive excursion in $\delta^{13} \mathrm{C}$ recorded in Trescléoux is not primarily influenced by lithologic changes. From all these observations, we consider that the carbonate carbon-isotope compositions did not suffer a diagenetic overprint and most likely represent primary oceanic values.

Because of its potential global significance, its data resolution hitherto unreached in the Oxfordian, and its accurate biostratigraphical dating, the $\mathrm{C}$-isotope record of the French section can be used as a reference for parts of the Early and for the Middle Oxfordian. For example, it is now possible to correlate the different ammonite zonations of SE France and northern Switzerland based on carbon-isotope stratigraphy (Fig. 6).

\subsection{Sedimentation pattern}

The pattern in sedimentation can be divided in both regions into two parts, with a turning point in the middle of the Oxfordian, where carbonate deposition greatly increased. The reduced carbonate accumulation before this turning point has been determined to be global and was explained with sea-level fall caused by an Ice Age at the Callovian-Oxfordian transition (Dromart et al., 2003a,b). It has been shown that continued carbonate deposition is essential to keep the earth liveable for 


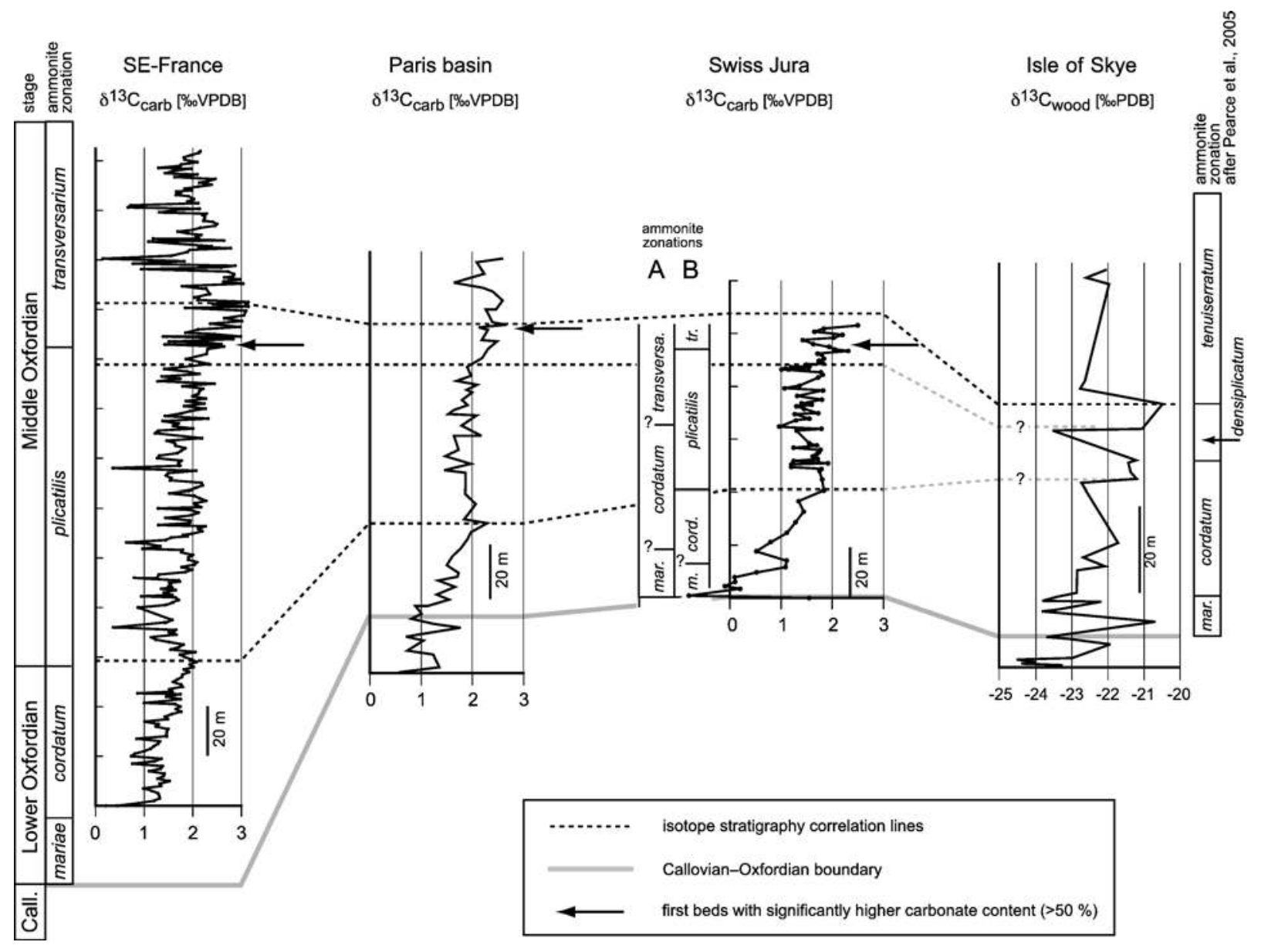

Fig. 6. Comparison between C-isotope records from different palaeoenvironments and from marine (SE France, Swiss Jura, Paris basin) and terrestrial material (Isle of Skye), showing the robustness and consistency of the signal. Liesberg section is shown with two ammonite biostratigraphic schemes: the regional Swiss zonation (Gygi, 2000) (A) and based on $\delta^{13} \mathrm{C}$-correlation with the Trescléoux/Oze section (B). Data taken from literature for Paris basin (Lavastre, 2002) and Isle of Skye (Pearce et al., 2005).

higher organisms (Berner and Caldeira, 1997), and that feedback mechanisms confine perturbations of the carbonate deposition to short durations in the order of a few 10 ky (Zeebe and Westbroek, 2003). The studied basinal sections still contain at least around $20 \%$ carbonates of partly pelagic origin. There are also records of flourishing carbonate platforms at that time (Fürsich et al., 2003; Vlahovic et al., 2005), so that the Early Oxfordian cannot be accounted as a time of a severe carbonate crisis. It was a time with ample sediment redistribution processes (strong shelf currents may have played an important role in this sediment redistribution as it is documented by the formation of hardgrounds in areas of lower palaeodepth along the northern Tethyan shelf (Kugler, 1987; Rais et al., 2005)). These processes masked a reduced but still continued carbonate accumulation. We propose that the recurrence of wide- spread carbonate accumulation was due to the warmer and more arid climate (Abbink et al., 2001), the availability of new habitats for carbonate platform communities through sea-level rise (Leinfelder et al., 2002), and changing ocean current systems (Abbink et al., 2001; Rais et al., 2005) which had a profound impact on nutrient distribution. The turnover in sedimentation pattern between the Early and the Middle Jurassic was not confined to the Western Tethys, but a global event (Dromart et al., 2003a).

\subsection{Organic matter burial and the mid-Oxfordian positive anomaly}

The lightest and most abundant isotope of carbon, ${ }^{12} \mathrm{C}$, is preferentially incorporated into organic matter. Therefore marine organic matter yields a $\delta^{13} \mathrm{C}$-signal 
with a mean value of about $-23 \%$ (Meyers, 1997), which is lower than the signal of the dissolved inorganic carbon (DIC, $\delta^{13} \mathrm{C} \sim 0 \%$ ) of the ocean reservoir. Longterm changes $\left(10^{4}\right.$ to $\left.10^{5} \mathrm{y}\right)$ in the isotopic composition of bulk marine carbonates are thought to reflect the variations of the isotopic signal of the DIC (Weissert, 1989). Excess burial of organic matter in the sediment (elevated $\mathrm{C}_{\text {org }} / \mathrm{C}_{\text {carb }}$ burial rate) leads to an enrichment of ${ }^{13} \mathrm{C}$ in the DIC. Accordingly, times of enhanced $\mathrm{C}_{\mathrm{org}}$ burial are recorded as trends to heavier values in bulk carbonate $\delta^{13} \mathrm{C}$-records, creating a positive excursion (Kump and Arthur, 1999). Excess burial of organic matter can be caused either by increased productivity and/or by enhanced preservation of organic matter in the sediment (Weissert, 1989). Models of the carbon cycle show that $\mathrm{C}_{\text {org }}$ burial is the most sensitive and most important factor that changes the $\mathrm{C}$-isotope signal of the DIC (Kump and Arthur, 1999), although not the only one. The C-isotopic composition of DIC can also be altered by variations in the input fluxes to the DICreservoir (e.g. enhanced degassing of mantle material or release of methane clathrates) or by changing the isotopic signal of the input fluxes (e.g. the signal of riverine input). However, there is no evidence for major variations in the input fluxes during the time interval investigated. There is also no indication for changes in the composition of carbonate in the fraction we are measuring as our bulk signal (i.e. micrite and microfossils), which may influence the C-isotope record in a given section (Swart and Eberli, 2005). For this reason we focus our discussion on the $\mathrm{C}_{\text {org }} / \mathrm{C}_{\text {carb }}$ burial rate.

So far, the Oxfordian C-isotope curve has only been reproduced in detail in Tethyan sections (e.g. Bartolini et al., 1996; Jenkyns, 1996; Lavastre, 2002; Wierzbowski, 2002; Pearce et al., 2005). Therefore it cannot be completely excluded that the curve records an isotopic change restricted to the Tethys ocean. However, our sampling resolution of 10 to $20 \mathrm{ky}$ is considerably longer than the ocean mixing time in the order of $10^{3} \mathrm{y}$ and therefore we assume that the Tethys pattern corresponds to the global C-isotope trend. Excess burial of organic carbon does not need to occur at the locality where a global shift to high $\delta^{13} \mathrm{C}$-values is recorded. This is used to explain, for example, why $\delta^{13} \mathrm{C}$ sometimes reaches maximum values only after the deposition of organic-rich black shales at a measured section (Menegatti et al., 1998). In the case of the studied sections, maximum values in $\delta^{13} \mathrm{C}$ postdate the deposition of organic-rich strata (Terres Noires, TOC up to $0.8 \%$ (Pellenard, 2003), and the Renggeri and Sornetan Members, TOC up to $1 \%$ ). In both sections, the steepest rise in $\delta^{13} \mathrm{C}$-values occurs within the first beds con- siderably enriched in carbonates (the uppermost beds of the Terres Noires and following Argovien, and the Liesberg Member, respectively). These beds record a lower $\mathrm{C}_{\text {org }} / \mathrm{C}_{\text {carb }}$ burial rate relative to their precursor sediments (Bombardiere and Gorin (2000) report TOC contents of only up to $0.25 \%$ for the Middle-Late Oxfordian carbonates in southeastern France). Consequently, the mechanism of excess burial of organic matter can only account for the mid-Oxfordian excursion if considerable amounts of organic matter were buried elsewhere. Many of the reported CallovianOxfordian black shale deposits have been dated as Middle Callovian (Dromart et al., 2003a and references therein; Kenig et al., 2004) and therefore cannot have caused the mid-Oxfordian positive excursion. There is one record of shales with TOC contents between 1 and $8.2 \%$ dated as Late Callovian-Early Oxfordian (Price and Gröcke, 2002), and one record of marine black shales continuously deposited from the Late Bathonian through the Volgian (Bausch et al., 1998). Furthermore, grey to black shales with an average TOC content of $1.7 \%$ reported from Nepal (Gradstein et al., 1991) were deposited from the Middle Oxfordian until the Late Tithonian. Thus, records of organic-rich Oxfordian sediments are rare and seem to represent local to regional phenomena rather than a condition of the global oceans (Pearce et al., 2005). If one wants to explain the steep positive shift (lower part of unit D) in the presented Cisotope record solely by a high $\mathrm{C}_{\text {org }} / \mathrm{C}_{\text {carb }}$ burial rate, the corresponding sediments need to be discovered yet.

In terms of amplitude, the mid-Oxfordian excursion is comparable to prominent positive anomalies related to black shales and oceanic anoxic events (OAE) such as the Valanginian Weissert OAE (Erba et al., 2004) and the Aptian Livello Selli (Menegatti et al., 1998). The Valanginian event is, however, of longer duration (almost two million years, Weissert and Erba (2004)); for the mid-Oxfordian positive anomaly in a strict sense, we roughly estimate a duration of 200 to $600 \mathrm{ky}$, according to numerical ages for ammonite zone boundaries (Jacquin et al., 1998). This is a further indication that somewhat different processes could have forced these excursions.

\subsection{Sea-level changes}

Some authors pointed out the possibility of a causal relationship between rising sea level and positive Cisotope anomalies (Weissert, 1989; Jenkyns, 1996). With an increasing surface of shelf flooded, more organic material may be buried in the sediment, leading to an increase in the $\delta^{13} \mathrm{C}$ of the seawater carbon reservoir. 
Jenkyns (1996) listed sections all over the world, where stratigraphic evidence for a mid-Oxfordian transgression exists, with maximum flooding apparently in the transversarium zone. He also measured carbon-isotopes in three sections in France and northern Italy and found the positive excursion in the transversarium zone. He concluded, that it could be related to the major transgressive event.

Second order sea-level cycles for southeast France (de Graciansky et al., 1999) show a transgression in late Callovian and earliest Oxfordian. The following regression lasted until early Late Oxfordian. Therefore, in SE France, transgression preceded the positive excursion. Looking at third order cycles at transversarium zone of Trescléoux (Gaillard et al., 2004), the positive excursion covers more than one complete cycle, starting with a highstand systems tract. More than half of the excursions amplitude is corresponding to a lowstand systems tract (Fig. 7). For northern Switzerland, two distinct major steps of sea-level rise in the late Early and early Middle Oxfordian have been suggested (Gygi, 1986), which also precede the onset of the positive excursion. Another sequence stratigraphic analysis for northern Switzerland placed a maximum flooding surface at the beginning of the transversarium zone (Pittet and Strasser, 1998), coinciding with the maximum values of the $\mathrm{C}$-isotope excursion.

On the other hand, it has been shown for northern Switzerland and adjacent parts of Germany and France, that regional to local tectonics may play an important role for relative sea level at a given place (Allenbach, 2001). Given the well-documented eustatic sea-level rise in the Late Jurassic (Hallam, 2001), this mechanism cannot be excluded as a possible cause for the observed positive excursion. Sea level could have reached a threshold in the Middle Oxfordian, providing vast areas

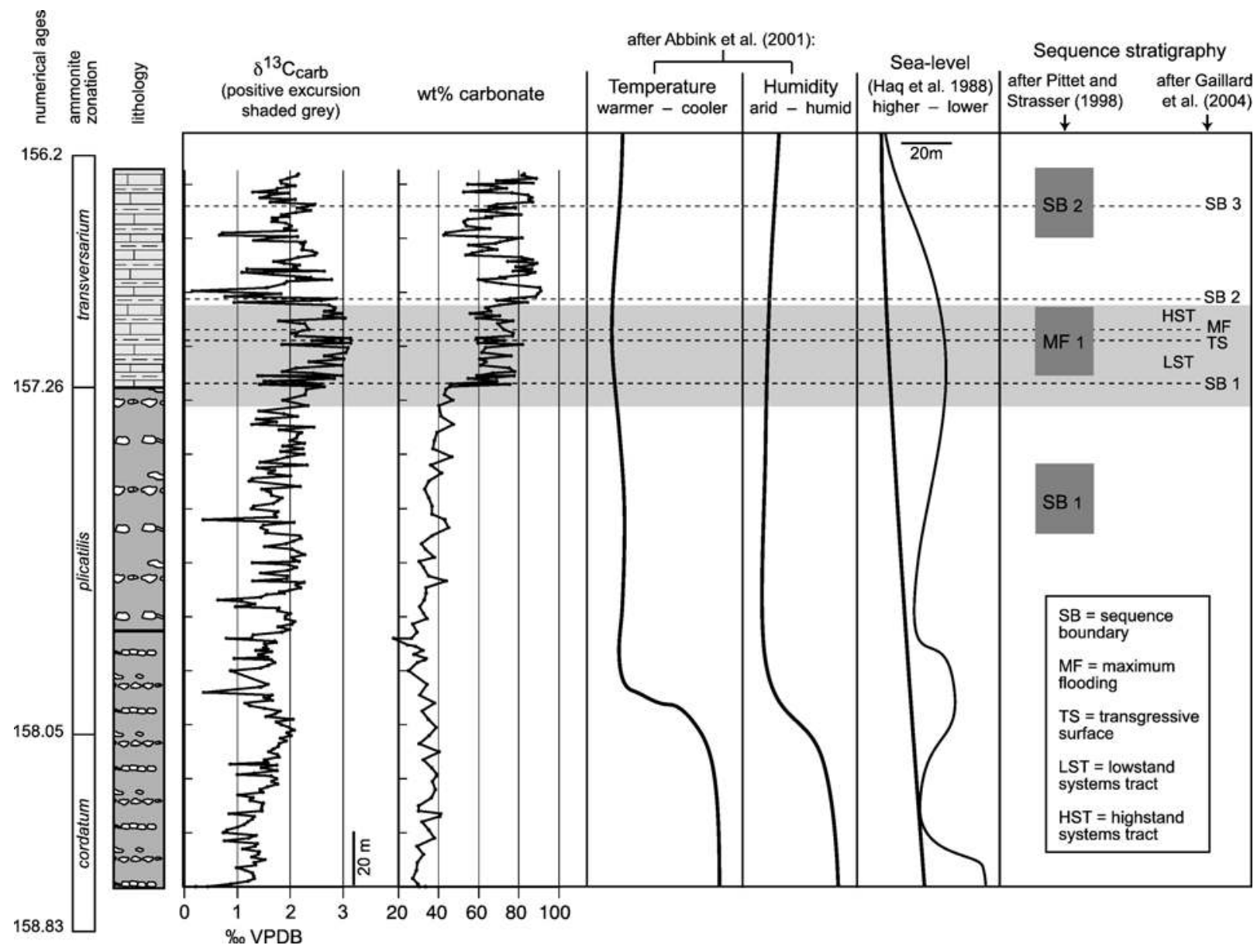

Fig. 7. Composite SE France reference section for Early to Middle Oxfordian carbon-isotope stratigraphy compared to climate reconstructions (Abbink et al., 2001), eustatic sea level (Haq et al., 1988), and sequence stratigraphy according to Pittet and Strasser (1998) and Gaillard et al. (2004). Numerical ages after Jacquin et al. (1998). 
of shallow depths. In these areas, high amounts of $\mathrm{C}_{\text {org }}$ may have been buried, resulting in high global $\delta^{13} \mathrm{C}$ values. However, as discussed above, the sedimentary record of the Oxfordian does not support such a scenario in that global black shale deposits are yet to be discovered - if they exist. Therefore further studies in a large number of environments are necessary to evaluate this possibility.

\subsection{Climate and/or ocean currents reorganisation}

Several studies have postulated a relatively cool and humid Late Callovian-Early Oxfordian climate, whereas the Middle and Late Oxfordian are characterised by warmer and more arid conditions (Bausch et al., 1998; Riboulleau et al., 1998; Riding and Hubbard, 1999; Abbink et al., 2001; Malchus and Steuber, 2002; Dromart et al., 2003b; Gröcke et al., 2003; Lécuyer et al., 2003). The onset of the warming was in the earliest Middle Oxfordian or plicatilis ammonite zone (Abbink et al., 2001; Malchus and Steuber, 2002; Dromart et al., 2003b). This pattern of climate change seems to be in agreement with the pattern of deposition of organic-rich sediments in the Callovian, in that warmer periods would favour the production of organic matter, and excess burial of organic matter in turn leads to cooling via drawdown of $\mathrm{CO}_{2}$ from the atmosphere (Dromart et al., 2003a). In contrast, our C-isotope record and the sedimentation pattern indicate that carbon cycle and climate were not closely coupled in the Oxfordian. The peak values of the positive excursion, equivalent to the establishment of a different carbon cycling mode, were reached during a time of progressive climate warming. On the other hand, they coincide with the widespread and pronounced change in sedimentation pattern in the transversarium ammonite zone towards a world dominated by carbonate deposition. Therefore, other factors like sea level played an import role in modifying the carbon cycle in the Oxfordian.

Climatic changes can occur as a response to various forcing factors such as reorganisation of ocean currents (e.g. Hotinski and Toggweiler, 2003), changes in atmosphere chemistry (e.g. Weissert and Erba, 2004), and earth-external factors like orbital parameters which change the amount of solar energy reaching the surface of the earth. For the warming in the Middle Oxfordian, both ocean current reorganisation and volcanism are possible forcing factors. The ocean reorganisation leading to a low-latitude circumglobal sea passage is well-documented (Ager and Walley, 1977; Vörös, 1993; Stille et al., 1996; Pellenard et al., 1999; Bombardiere and Gorin, 2000; Bill et al., 2001; Leinfelder et al.,
2002; Rais et al., 2005). Model results suggest that such a circumglobal sea passage initiates an ocean current system which effectively distributes energy from low to high latitudes (Hotinski and Toggweiler, 2003). This would then diminish latitudinal temperature gradients and lead to higher temperatures in subtropical and temperate zones. Higher temperatures could also enhance precipitation on certain parts of the continents (Moore et al., 1992) - which may be recorded in the rising trend in ${ }^{87} \mathrm{Sr} /{ }^{86} \mathrm{Sr}$ after the Middle Oxfordian, and which does not need to contradict information from palaeobotany which indicates more arid conditions in Middle Oxfordian northern Europe (Abbink et al., 2001). An altered current system coupled to sea-level rise also matches the observed sedimentary pattern: enhanced carbonate sedimentation in the Oxfordian starts only with sea-level rise and the reorganisation of the ocean current system.

A changing atmosphere chemistry also could have caused the observed temperature rise. However, proxy and model records of $p \mathrm{CO}_{2}$ for the Oxfordian are not consistent, as they vary between one and 15 times as much $\mathrm{CO}_{2}$ as today (Yapp and Poths, 1996; Berner and Kothavala, 2001; Retallack, 2001; Rothman, 2002; Edmond and Huh, 2003). These reconstructions show generally resolutions of one data point for several million years and are thus not useful in the timescales studied here. Reconstructions of palaeo- $p \mathrm{CO}_{2}$ in a resolution comparable to our $\delta^{13} \mathrm{C}$-record could give further hints on climate history.

\section{Conclusions}

The investigated sections in France (Trescléoux/Oze) and Switzerland (Liesberg) record a likely global signal in $\delta^{13} \mathrm{C}$. This signal includes a distinct positive excursion in the second part of the Middle Oxfordian, with an amplitude of $1.5 \%$, peak values of $3.1 \%$, and a duration of roughly $400 \mathrm{ky}$ (average estimation). This mid-Oxfordian positive anomaly is assigned to the latest plicatilis-early transversarium ammonite zones. We propose that the presented carbon-isotope record for the Early and Middle Oxfordian is used as reference for Oxfordian C-isotope stratigraphy.

The cause of the Oxfordian C-isotope excursion remains enigmatic. So far, there is no evidence for largescale volcanism triggering greenhouse conditions, and the excursion seems not to coincide with a global oceanic anoxic event. The turning point of the excursion coincides with a major change in Tethyan sedimentation pattern. This was also the time of a profound rearrangement of the oceanic current system induced by the 
establishment of a new circumglobal ocean passage in low latitudes. This modification very likely increased temperatures by about $5{ }^{\circ} \mathrm{C}$ in middle latitudes and increased nutrient concentrations in surface water due to intensified upwelling (Hotinski and Toggweiler, 2003). This resulted in increased $\mathrm{C}_{\text {org }}$ production and burial, leading to the positive excursion in $\mathrm{C}$-isotope records as ${ }^{12} \mathrm{C}$ was preferentially removed from the ocean system. Increased $\mathrm{C}_{\text {org }}$ burial also caused an intermittent decrease of atmospheric $p \mathrm{CO}_{2}$ values. These conditions culminated at the turning point of the Middle Oxfordian $\mathrm{C}$-isotope curve. This turning point marks the transition to a new mode of carbon cycling, which obviously favoured widespread reef and carbonate platform growth at a time of rising sea level (which created new shallow water habitats) and carbonate-dominated sedimentation in basinal settings.

\section{Acknowledgments}

Financial support from Swiss National Science Foundation is thankfully acknowledged. We thank Dominique Fortwengler for guidance in the field in SE France, Maria Coray-Strasser for help with sample preparation and analysis, and Nele Meckler and an anonymous referee for helpful comments on an earlier version of this paper. We further thank Finn Surlyk, Alaistair Ruffell and an anonymous reviewer for helpful criticism.

\section{References}

Abbink, O., Targarona, J., Brinkhuis, H., Visscher, H., 2001. Late Jurassic to earliest Cretaceous paleoclimatic evolution of the southern North Sea. Global and Planetary Change 30, 231-256.

Ager, D.V., Walley, C.D., 1977. Mesozoic brachiopod migrations and the opening of the North Atlantic. Palaeogeography, Palaeoclimatology, Palaeoecology 21, 85-99.

Allenbach, R.P., 2001. Synsedimentary tectonics in an epicontinental sea: a new interpretation of the Oxfordian basins of northern Switzerland. Eclogae Geologicae Helveticae 94, 265-287.

Bartolini, A., Baumgartner, P.O., Hunziker, J., 1996. Middle and Late Jurassic carbon stable-isotope stratigraphy and radiolarite sedimentation of the Umbria-Marche Basin (Central Italy). Eclogae Geologicae Helveticae 89, 811-844.

Bausch, W.M., Birkenmajer, K., Grunenberg, T., Krajewski, K.P., Kutyba, J., 1998. Clay-mineralogy of Jurassic marine black shales in Spitsbergen: a possible evidence for climate cooling during Oxfordian. Bulletin of the Polish Academy of Sciences. Earth Sciences 46, 211-221.

Berner, R.A., Caldeira, K., 1997. The need for mass balance and feedback in the geochemical carbon cycle. Geology 25, 955-956.

Berner, R.A., Kothavala, Z., 2001. GEOCARB III: a revised model of atmospheric $\mathrm{CO}_{2}$ over phanerozoic time. American Journal of Science 301, 182-204.
Bill, M., O’Dogherty, L., Guex, J., Baumgartner, P.O., Masson, H., 2001. Radiolarite ages in Alpine-Mediterranean ophiolites: constraints on the oceanic spreading and the Tethys-Atlantic connection. GSA Bulletin 113, 129-143.

Bombardiere, L., Gorin, G.E., 2000. Stratigraphical and lateral distribution of sedimentary organic matter in upper Jurassic carbonates of SE France. Sedimentary Geology 132, 177-203.

Cogné, J.-P., Humler, E., 2004. Temporal variation of oceanic spreading rate and crustal production rates during the last 180 My. Earth and Planetary Science Letters 227, 427-439.

Collin, P.Y., Loreau, J.P., Courville, P., 2005. Depositional environments and iron ooid formation in condensed sections (CallovianOxfordian, south-eastern Paris basin, France). Sedimentology 52, 969-985.

de Graciansky, P.-C., Dardeau, G., Bodeur, Y., Elmi, S., Fortwengler, D., Jacquin, T., Marchand, D., Thierry, J., 1999. Les Terres Noires du sud-est de la France (Jurassique moyen et supérieur): interprétation en termes de stratigraphie séquentielle. Bull. Centre Rech. Elf Explor. Prod. 22, 35-69.

Dromart, G., Garcia, J.-P., Gaumet, F., Picard, S., Rousseau, M., Atrops, F., Lecuyer, C., Sheppard, S.M.F., 2003a. Perturbation of the carbon cycle at the Middle-Late Jurassic transition: geological and geochemical evidence. American Journal of Science 303, 667-707.

Dromart, G., Garcia, J.P., Picard, S., Atrops, F., Lécuyer, C., Sheppard, S.M.F., 2003b. Ice age at the Middle-Late Jurassic transition? Earth and Planetary Science Letters 213, 205-220.

Edmond, J.M., Huh, Y., 2003. Non-steady state carbonate recycling and implications for the evolution of atmospheric $p \mathrm{CO}_{2}$. Earth and Planetary Science Letters 216, 125-139.

Erba, E., Bartolini, A., Larson, R.L., 2004. Valanginian Weissert oceanic anoxic event. Geology 32, 149-152.

Fischer, H., 1965. Oberer Dogger und unterer Malm des Berner Jura: Tongruben von Liesberg. Bull. Ver. Schweiz. Petrol.-Geol. u. -Ing. $31,25-36$

Féraud, G., Alric, V., Fornari, M., Bertrand, H., Haller, M., 1999. ${ }^{40} \mathrm{Ar} /{ }^{39} \mathrm{Ar}$ dating of the Jurassic volcanic province of Patagonia: migrating magmatism related to Gondwana break-up and subduction. Earth and Planetary Science Letters 172, 83-96.

Fürsich, F.T., Wilmsen, M., Seyed-Emami, K., Schairer, G., Majidifard, M.R., 2003. Platform-basin transect of a Middle to Late Jurassic large-scale carbonate platform system (Shotori Mountains, Tabas Area, East-Central Iran). Facies 48, 171-198.

Gaillard, C., Atrops, F., Marchand, D., Hanzo, M., Lathuilière, B., Bodeur, Y., Ruget, C., Nicollin, J.-P., Werner, W., 1996. Description stratigraphique préliminarie des faisceaux alternants de l'Oxfordien moyen dans le bassin dauphinois (Sud-Est de la France). Géologie de la France 1, 17-24.

Gaillard, C., Emmanuel, L., Hanzo, M., Lathuilière, B., Atrops, F., Bodeur, Y., Bouhamdi, A., Marchand, D., Enay, R., Ruget, C., Werner, W., 2004. Une séquence disséquée du bassin à la plateforme: l'épisode carbonaté de l'Oxfordien moyen dans le Sud-Est de la France. Bulletin de la Societe Géologique France 175, 107-119.

Gradstein, F.M., Gibling, M.R., Sarti, M., Von Rad, U., Thurow, J.W., Ogg, J.G., Jansa, L.F., Kaminski, M.A., Westermann, G.E.G., 1991. Mesozoic Tethyan strata of Thakkhola, Nepal, evidence for the drift and breakup of Gondwana. Palaeogeography, Palaeoclimatology, Palaeoecology 88, 193-218.

Gradstein, F.M., Ogg, J.G., Smith, A.G., Bleeker, W., Lourens, L.J., 2004. A new geologic time scale, with special reference to Precrambian and Neogene. Episodes 27, 83-100. 
Gröcke, D.R., Price, G.D., Ruffell, A.H., Mutterlose, J., Baraboshkin, E., 2003. Isotopic evidence for Late Jurassic-Early Cretaceous climate change. Palaeogeography, Palaeoclimatology, Paleoecology $202,97-118$.

Gygi, R.A., 1986. Eustatic sea level changes of the Oxfordian (Late Jurassic) and their effect documented in sediments and fossil assemblages of an epicontinental sea. Eclogae Geologicae Helvetiae 79, 455-491.

Gygi, R.A., 1990. The Oxfordian ammonite succession near Liesberg BE and Péry BE, northern Switzerland. Eclogae Geologicae Helvetiae 83, 177-199.

Gygi, R., 2000. Integrated stratigraphy of the Oxfordian and Kimmeridgian (Late Jurassic) in northern Switzerland and adjacent southern Germany. Denkschriften der Schweizerischen Akademie der Naturwissenschaften, vol. 104. Birkhäuser, Basel.

Gygi, R.A., Persoz, F., 1987. The epicontinental sea of Swabia (southern Germany) in the Late Jurassic - factors controlling sedimentation. Neues Jahrbuch fur Geologie und Paläontologie Abhandlungen 176, 49-65.

Hallam, A., 2001. A review of the broad pattern of Jurassic sea-level changes and their possible causes in the light of current knowledge. Palaeogeography, Palaeoclimatology, Paleoecology 167, 23-37.

Haq, B.U., Hardenbol, J., Vail, P.R., 1988. Mesozoic and Cenozoic chronostratigraphy and cycles of sea level change. In: Wilgus, C.K., et al. (Eds.), Sea-level Changes: An Integrated Approach. SEPM Spec. Publ., pp. 71-108.

Hotinski, R.M., Toggweiler, J.R., 2003. Impact of a Tethyan circumglobal passage on ocean heat transport and "equable" climates. Paleoceanography 18, 1007.

Jacquin, T., de Graciansky, P.-C., Vail, P.R., 1998. Jurassic sequence cycle chart for Western European basins. In: de Graciansky, P.-C., Hardenbol, J., Jacquin, T., Vail, P.R. (Eds.), Mesozoic and Cenozoic Sequence Stratigraphy of European Basins. SEPM Special Publication.

Jenkyns, H.C., 1996. Relative sea-level change and carbon isotopes: data from the upper Jurassic (Oxfordian) of central and Southern Europe. Terra Nova 8, 75-85.

Jenkyns, H.C., Jones, C.E., Gröcke, D.R., Hesselbo, S.P., Parkinson, D.N., 2002. Chemostratigraphy of the Jurassic system: applications, limitations and implications for paleoceanography. Journal of the Geological Society, London 159, 351-378.

Katz, M.E., Wright, J.D., Miller, K.G., Cramer, B.S., Fennel, K., Falkowski, P.G., 2005. Biological overprint of the geological carbon cycle. Marine Geology 217, 323-338.

Kenig, F., Hudson, J.D., Sinninghe Damsté, J.S., Popp, B.N., 2004. Intermittent euxinia: reconciliation of a Jurassic black shale with its biofacies. Geology 32, 421-424.

Kugler, C., 1987. Die Wildegg Formation im Ostjura und die SchiltFormation im östlichen Helvetikum - ein Vergleich. Ph. D. Thesis. Mitt. Geol. Inst. ETH Zürich N.F. 259.

Kump, L.R., Arthur, M.A., 1999. Interpreting carbon-isotope excursions: carbonates and organic matter. Chemical Geology 161, 181-198.

Lavastre, V., 2002. Evènements sédimentaires, diagénétiques et postdiagénétiques dans la formation argileuse du Callovo-Oxfordien (Bassin de Paris, France): enregistrement isotopique des minéraux et de l'eau porale. Thesis, Université Paris VII.

Leinfelder, R.R., Schmid, D.U., Nose, M., Werner, W., 2002. Jurassic reef patterns; the expression of a changing globe. In: Kiessling, W., Flügel, E., Golonka, J. (Eds.), Phanerozoic reef patterns. Special Publication - Society for Sedimentary Geology, pp. $465-520$.
Lécuyer, C., Picard, S., Garcia, J.-P., Sheppard, S.M.F., Grandjean, P., Dromart, G., 2003. Thermal evolution of Tethyan surface waters during the Middle-Late Jurassic: evidence from $\delta^{18} \mathrm{O}$ values of marine fish teeth. Paleoceanography 18, 1076.

Maheshwari, A., Sial, A.N., Mathur, S.C., Tripathi, R.P., 2003. $\delta^{13} \mathrm{C}$ Variations in Late Jurassic Carbonates, Jaisalmer Formation, Western India. Gondwana Research 6, 931-934.

Malchus, N., Steuber, T., 2002. Stable isotope records (O, C) of Jurassic aragonite shells from England and NW Poland: palaeoecologic and environmental implications. Geobios 35, 29-39.

Marshall, J.D., 1992. Climatic and oceanographic isotopic signals from the carbonate rock record and their preservation. Geological Magazine 129, 143-160.

Menegatti, A.P., Weissert, H., Brown, R.S., Tyson, R.V., Farrimond, P., Strasser, A., Caron, M., 1998. High-resolution $\delta^{13} \mathrm{C}$ stratigraphy through the early Aptian "Livello Selli" of the Alpine Tethys. Paleoceanography 13, 530-545.

Meyers, P.A., 1997. Organic geochemical proxies of paleoceanographic, paleolimnologic, and paleoclimatic processes. Organic Geochemistry 27, 213-250.

Moore, G.T., Hayashida, D.N., Ross, C.A., Jacobson, S.R., 1992. Paleoclimate of the Kimmeridgian/Tithonian (Late Jurassic) world: results using a general circulation model. Palaeogeography, Palaeoclimatology, Palaeoecology 93, 47-72.

Padden, M., Weissert, H., de Rafelis, M., 2001. Evidence for Late Jurassic release of methane from gas hydrate. Geology 29, 223-226.

Padden, M., Weissert, H., Funk, H., Schneider, S., Gansner, C., 2002. Late Jurassic lithological evolution and carbon-isotope stratigraphy of the western Tethys. Eclogae Geologicae Helveticae 95, 333-346.

Pearce, C.R., Hesselbo, S.P., Coe, A.L., 2005. The mid-Oxfordian (Late Jurassic) positive carbon-isotope excursion recognised from fossil wood in the British Isles. Palaeogeography, Palaeoclimatology, Palaeoecology 221, 343-357.

Pellenard, P., 2003. Message terrigène et influences volcaniques au Callovien-Oxfordien dans les bassins de Paris et du sud-est de la France. Mém. Soc. Géol. Nord. 362 pp.

Pellenard, P., Deconinck, J.-F., Marchand, D., Thierry, J., Fortwengler, D., Vigneron, G., 1999. Contrôle géodynamique de la sedimentation argileuse du Callovien-Oxfordien moyen dans l'Est du bassin de Paris: influence eustatique et volcanique. Comptes Rendus de l'Academie des Science Paris 328, 807-813.

Pellenard, P., Deconinck, J.-F., Huff, W.D., Thierry, J., Marchand, D., Fortwengler, D., Trouiller, A., 2003. Characterization and correlation of Upper Jurassic (Oxfordian) bentonite deposits in the Paris Basin and the Subalpine Basin, France. Sedimentology 50, 1035-1060.

Pittet, B., Strasser, A., 1998. Long-distance correlations by sequence stratigraphy and cyclostratigraphy: examples and implications (Oxfordian from the Swiss Jura, Spain, and Normandy). Geologische Rundschau 86, 852-874.

Price, G.D., Gröcke, D.R., 2002. Strontium-isotope stratigraphy and oxygen- and carbon-isotope variation during the Middle JurassicEarly Cretaceous of the Falkland Plateau, South Atlantic. Palaeogeography, Palaeoclimatology, Paleoecology 183, 209-222.

Rais, P., Louis, B., Bernasconi, S., Weissert, H., 2005. Evidence for changes in intermediate-water currents in the Alpine Tethys during the Late Jurassic, EGU05. Geophysical Research Abstracts 7, 06583.

Retallack, G.J., 2001. A 300-million-year record of atmospheric carbon dioxide from fossil plant cuticles. Nature 411, 287-290. 
Riboulleau, A., Baudin, F., Daux, V., Hantzpergue, P., Renard, M., Zakharov, V., 1998. Évolution de la paléotempérature des eaux de la plate-forme russe au cours du Jurassique supérieur (Sea surface paleotemperature evolution of the Russian Platform during the Upper Jurassic). Comptes Rendus de l'Academie des Science Paris, Sciences de la Terre et des Planètes 326, 239-246.

Riding, J.B., Hubbard, R.N.L.B., 1999. Jurassic (Toarcian to Kimmeridgian) dinoflagellate cysts and paleoclimates. Palynology $23,15-30$

Rothman, D.H., 2002. Atmospheric carbon dioxide levels for the last 500 million years. PNAS 99, 4167-4171.

Stampfli, G.M., Borel, G.D., 2002. A plate tectonic model for the Paleozoic and Mesozoic constrained by dynamic plate boundaries and restored synthetic oceanic isochrons. Earth and Planetary Science Letters 196, 17-33.

Stille, P., Steinmann, M., Riggs, S.R., 1996. Nd isotope evidence for the evolution of the paleocurrents in the Atlantic and Tethys Oceans during the past $180 \mathrm{Ma}$. Earth and Planetary Science Letters 144, 9-19.

Swart, P.K., Eberli, G., 2005. The nature of the $\delta^{13} \mathrm{C}$ of periplatform sediments: implications for stratigraphy and the global carbon cycle. Sedimentary Geology 175, 115-129.

Vakhrameev, V.A., 1991. Jurassic and Cretaceous Floras and Climates of the Earth. Cambridge University Press, Cambridge. 318 pp.

van Aarssen, B.G.K., Alexander, R., Kagi, R.I., 2000. Higher plant biomarkers reflect palaeovegetation changes during Jurassic times. Geochimica et Cosmochimica Acta 64, 1417-1424.

Vincent, B., Emmanuel, L., Loreau, J.-P., 2004. Signification du signal isotopique $\left(\delta^{18} \mathrm{O}, \delta^{13} \mathrm{C}\right)$ des carbonates néritiques: composante diagénétique et composante originelle (Jurassique supérieur de l'est du bassin de Paris, France). Compte Rendu Geoscience 336, 29-39.

Vlahovic, I., Tišljar, J., Velic, I., Maticec, D., 2005. Evolution of the Adriatic Carbonate Platform: palaeogeography, main events and depositional dynamics. Palaeogeography, Palaeoclimatology, Palaeoecology 220, 333-360.
Vörös, A., 1993. Jurassic microplate movements and brachiopod migrations in the western part of the Tethys. Palaeogeography, Palaeoclimatology, Palaeoecology 100, 125-145.

Weissert, H., 1989. C-isotope stratigraphy, a monitor of paleoenvironmental change: a case study from the early Cretaceous. Surveys in Geophysics 10, 1-61.

Weissert, H., Breheret, J.G., 1991. A carbonate carbon-isotope record from Aptian-Albian sediments of the Vocontian Trough (SE France). Bulletin de la Societe Géologique de France 162, $1133-1140$.

Weissert, H., Erba, E., 2004. Volcanism, $\mathrm{CO}_{2}$ and palaeoclimate: a Late Jurassic-Early Cretaceous carbon and oxygen isotope record. Journal of the Geological Society, London 161, 695-702.

Weissert, H., Mohr, H., 1996. Late Jurassic climate and its impact on carbon cycling. Palaeogeography, Palaeoclimatology, Paleoecology $122,27-43$.

Wierzbowski, H., 2002. Detailed oxygen and carbon isotope stratigraphy of the Oxfordian in Central Poland. International Journal of Earth Science (Geologische Rundschau) 91, 304-314.

Yapp, C.J., Poths, H., 1996. Carbon isotopes in continental weathering environments and variations in ancient atmospheric $\mathrm{CO}_{2}$ pressure. Earth and Planetary Science Letters 137, 71-82.

Zeebe, R.E., Westbroek, P., 2003. A simple model for the $\mathrm{CaCO}_{3}$ saturation state of the ocean: the "Strangelove", the "Neritan", and the "Cretan" Ocean. Geochemistry Geophysical Geosystem 4, 1104.

Ziegler, P.A., 1988. Evolution of the Arctic-North Atlantic and the Western Tethys. AAPG Memoir 43.

Ziegler, P.A., Cloetingh, S., Guiraud, R., Stampfli, G.M., 2001. PeriTethyan platforms: constraints on dynamics of rifting and basin inversion. In: Ziegler, P.A., Cavazza, W., Robertson, A.H.F., Crasquin-Soleau, S. (Eds.), Peri-Tethys Memoir 6: Peri-Tethyan Rift/Wrench Basins and Passive Margins. Mém. Mus. natn. Hist. nat., Paris, pp. 9-49. 